\title{
Sofle
}

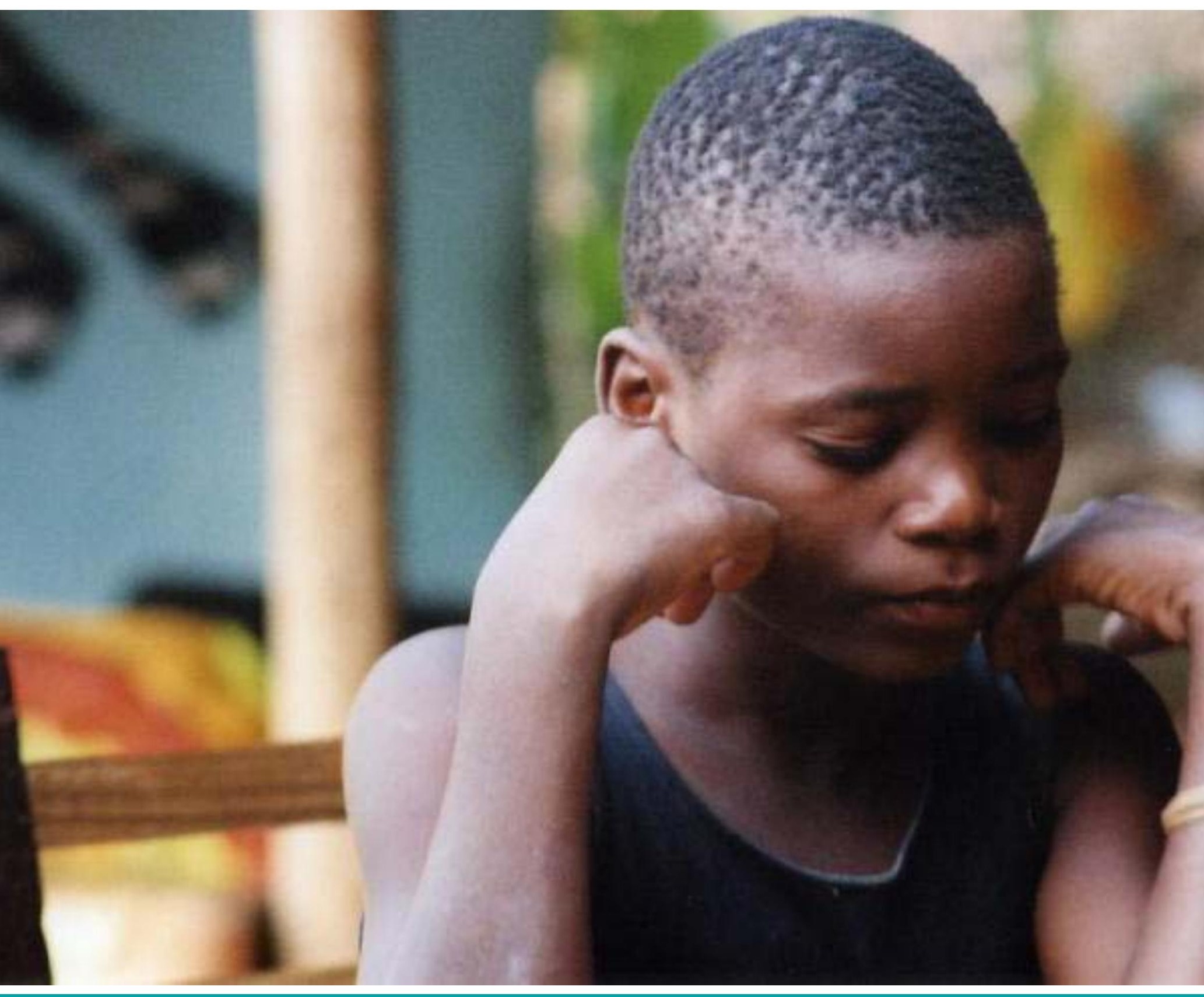

SOFIE Opening Up Access Series No 5

\section{Keeping children in school: A review of open education policies in Lesotho and Malawi}

Chris Yates

Institute of Education, University of London 
Cover photo: (c) Rachel Wood

Published by SOFIE

(C) 2008 Institute of Education, University of London

SOFIE is a three year Research Project supported by the UK Department for International Development (DFID) and the Economic and Social Science Research Council (ESRC). Its purpose is to strengthen open, distance and flexible learning (ODFL) systems and structures to increase access to education for young people living in high HIV prevalence areas in Malawi and Lesotho. It seeks to achieve this through developing a new, more flexible model of education that uses ODFL to complement and enrich conventional schooling. It also seeks to encourage application of the new knowledge generated through effective communication to development agencies, governments, development professionals, non-governmental organisations and other interested stakeholders.

Access to education and learning is being viewed as a 'social vaccine' for HIV but in high prevalence areas orphans and other vulnerable children are frequently unable to go to school regularly and are thus being deprived of the very thing they need to help protect themselves from infection. In this context sustained access is critical to long term improvements in risk and vulnerability and it requires new models of education to be developed and tested.

The partners

The research team is led from the Department of Education and International Development, Institute of Education, University of London and the research is being developed collaboratively with partners in subSaharan Africa.

Lead partner

The Department of Education and International Development, Institute of Education, University of London: Dr. Pat Pridmore and Mr. Chris Yates

Collaborating partners

The South African Institute for Distance Education (SAIDE): Ms. Tessa Welch and Mr. Ephraim Mhlanga The Institute of Education, National University of Lesotho: Dr. Thabiso Nyabanyaba

Centre for Education Research and Training (CERT), University of Malawi: Ms. Catherine Moleni

Disclaimer

The research on which this paper is based was commissioned by the SOFIE Project (www.ioe.ac.uk/sofie). The views expressed are those of the author(s) and not necessarily those of the SOFIE Team.

ISBN 978-1-906648-04-6

\section{SOFIE}

Department of Education and International Development Institute of Education
20 Bedford Way

London

WC1H OAL

United Kingdom
Tel: + 44 (0) 2076126152

Website: www.ioe.ac.uk/sofie

Email: m.harri@ioe.ac.uk 


\title{
Keeping children in school: A review of open education policies in Lesotho and Malawi
}

\author{
Chris Yates \\ Institute of Education, University of London
}

SOFIE Opening Up Access Series No 5 


\begin{abstract}
This paper looks at the situation of out of school children in Lesotho and Malawi in the context of HIVIAIDS and the role that open and distance and flexible learning might come to play in the future. It provides a brief consideration of scale and nature of exclusion, before moving on to look at some of the recent history of theories of inclusion and exclusion. The paper then provides a review of government policies in Lesotho and Malawi with respect to improving access to, and equity through, education for out of school youth particularly in the areas of non formal education, information and communication technologies, and HIVIAIDS. The paper concludes by reflecting on what the review points to, in relation to some of the questions being posed by the research project.
\end{abstract}




\section{Table of Contents}

Abstract

List of tables

List of abbreviations $\quad 7$

$\begin{array}{lr}\text { Overview } & 9\end{array}$

1. Introduction and the context of the review 9

1.1 Introduction $\quad 9$

$\begin{array}{ll}1.2 \text { Definition of ODFL } & 10\end{array}$

1.3 The Lesotho-Malawi development picture 10

2. Who is out of school and who has school failed? The unlucky generations 11

2.1 Out of primary school 12

$\begin{array}{lr}\text { 2.2.1 Lesotho } & 13\end{array}$

$\begin{array}{ll}2.2 .2 \text { Malawi } & 13\end{array}$

$\begin{array}{ll}2.2 \text { Out of secondary school } & 14\end{array}$

$\begin{array}{lr}2.3 \text { Adult literacy } & 14\end{array}$

3. Theories of inclusion/exclusion 15

$\begin{array}{lr}\text { 4. Policies } & 17\end{array}$

4.1 The formal education system 18

4.2 The non-formal education system 18

4.2.1 Lesotho: Non-formal Education Policy 18

4.2.2 Malawi: Non-formal Education (NFE) Policy 19

$\begin{array}{ll}4.3 \text { ICT policies } & 19\end{array}$

4.3.1 Lesotho: National ICT Policy 19

4.3.2 Malawi National ICT Policy 20

4.4 HIV and AIDS policies 20

4.4.1 Lesotho: National AIDS Policy $\quad 20$

$\begin{array}{ll}\text { 4.4.2 Malawi National AIDS policy } & 21\end{array}$

4.5 Other policies

4.5.1 Malawi Policy on Teenage Pregnancy and School Re-entry 22

5. Conclusion and way forward 22

$\begin{array}{ll}\text { References } & 24\end{array}$ 


\section{List of tables}

Table 1: Lesotho and Malawi - Basic social indicators 11

Table 2: HIVIAIDS $\quad 11$

Table 3: Education access and performance and the Education Development Index (EDI) 11

Table 4: Out of school primary children 13

Table 5: Malawi: Net Attendance Ratio 13

Table 6: Secondary school push out - Numbers of children failing to complete secondary education 14

Table 7: Adult literacy 1990-2004/2015 14

Table 8: Youth literacy and illiteracy rates 1990-2004 - with partial 2015 projections 15

Table 9: Evolution of notions of Exclusion-Inclusion with respect to Education Provision for All

Table 10: Lesotho - National Goals for NFE 


\section{List of abbreviations}

\begin{tabular}{|c|c|}
\hline ADB & African Development Bank \\
\hline AIDS & Acquired Immune Deficiency Syndrome \\
\hline DE & Distance Education \\
\hline DEC & Distance Education Centres \\
\hline DFID & Department for International Development (UK) \\
\hline EDI & Education For All Development Index \\
\hline EFA & Education For All \\
\hline ESRC & Economic and Social Research Council \\
\hline GDP & Gross Domestic Product \\
\hline GNP & Gross National Product \\
\hline GER & Gross Enrolment Rate \\
\hline GoM & Government of Malawi \\
\hline GoL & Government of Lesotho \\
\hline HDI & Human Development Index \\
\hline HIV & Human Immunodeficiency Virus \\
\hline ICT & Information and Communications Technology \\
\hline IEMS & Institute of Extra-Mural Studies \\
\hline LANFE & Lesotho Association for Non-Formal Education \\
\hline LDTC & Lesotho Distance Teaching Centre \\
\hline MCDE & Malawi College of Distance Education \\
\hline MDGs & Millennium Development Goals \\
\hline MOE & Ministry of Education (Lesotho) \\
\hline MOEVT & Ministry of Education and Vocational Training (Malawi) \\
\hline NAC & National Aids Commission (Lesotho) \\
\hline NFE & Non-Formal Education \\
\hline NER & Net Enrolment Rate \\
\hline NESP & National Education Sector Plan \\
\hline NGO & Non Governmental Organisation \\
\hline ODFL & Open Distance and Flexible Learning \\
\hline SADC & Southern African Development Community \\
\hline SEN & Special Needs Education \\
\hline UNAIDS & Joint United Nations Programme on HIV and AIDS \\
\hline UNDP & United Nations Development Programme \\
\hline UNESCO & United Nations Educational Scientific and Cultural Organisation \\
\hline WDR & World Development Report \\
\hline WHO & World Health Organization \\
\hline
\end{tabular}


...regardless of the context or era, inclusive education is about little else than the politics of recognition. (Ware, 2004, paraphrasing Slee, 2004: 5).

The idea of a useless surplus is one of the most dangerous of all social propositions, particularly when associated with the assignation of moral turpitude and worthlessness to the apparently surplus poor (Byrne, 2005:21).

\section{Overview}

This paper looks at the situation of out of school children in Lesotho and Malawi in the context of HIVIAIDS and the role that open and distance and flexible learning might come to play in the future. The paper is divided into five sections. Section 1 introduces the paper and provides its focus, rationale and a definition of key terms. Section 2 looks at the size and nature of those who are presently outside school, either because they have been pushed out or dropped out, or because they have failed to obtain access. Section 3 reviews some recent theories of inclusion and exclusion with regard to schooling provision. Section 4 identifies policy developments that have been taken by the two governments with regard to promoting more open and inclusive education and training opportunities for youth and young adults. Section 5 concludes with a brief consideration of the implications of the discussion for the research questions we have posed for our study.

\section{Introduction and the context of the review}

\subsection{Introduction}

It is recognised that there is a dearth of policy which deals specifically with open, distance and flexible learning (ODFL) (Lentell, 2004) particularly in sub-Saharan Africa (Yates and Pontefract, 2006). As a result, initiatives have often been piecemeal, fragmented, and unsustainable. Innovations designed to try to improve social equity and educational inclusion, have frequently floundered as a result of the poorly developed policy context (Butcher, 2005). ODFL is not alone in this however. Significantly, other areas of mainstream education in low-resource economies also lack policies to guide development. For example, after completing a large-scale five-country study of teacher education Lewin and Stuart (2003:177) concluded that the unavailability of well-developed policies for teacher education was a serious constraint.

I have argued elsewhere that there are basically two ways to go for educational planners and social entrepreneurs seeking to better serve out of school youth and denied adults with improved lifelong learning opportunities. I have termed these approaches parallelism and integration (Yates, 2000). With the parallel approach, ODFL develops separate institutions, structures and programmes that are largely parasitic upon the mainstream educational system for educational space and professional inputs. Schools provide spaces for distance learners in the evenings or weekends and conventional teachers act as part-time materials developers, tutors, and assignment markers. In contrast, the integrationist approach pursues a different strategy, seeking to work more directly with and within the mainstream, trying to engineer alternative delivery modalities using new media and pedagogy from within the schools themselves. Here conventional mainstream provision agrees to become more responsive and flexible in order to better serve new audiences previously excluded by the relatively closed nature of the face-to-face mode.

The policy context is a very important determinant of what can be achieved with regard to those out of school, especially long term. There is some evidence that both Lesotho and Malawi are now switching from their earlier parallel strategies to a more integrated approach (see for example Lesotho Education Sector Strategic Plan 2005-2015 Chapter 8 and The Malawi National Education Sector Plan 2006 - Secondary analysis). Although, this shift 
initially seems to downgrade the importance and achievements of the parallel precursor forms of distance education (DE) in both countries, the growing severity of the Education for All (EFA) challenge and the magnitude of possible failure, suggest that a closer more effective integration in the future may be important.

Thirty years ago the Marxist critique of schooling in the West helped to explain how processes of social reproduction served to perpetuate exclusion and inequality (see for example Bowles and Gintis, 1976; Bourdieu and Passeron, 1977; Willis, 1977; Apple, 1982). This argument has rested on the tendency of competitive schooling to reproduce rather than mitigate or redistribute social inequality - though a recent analysis in Cuba has interestingly shown how highly structured, state controlled, yet competitive education systems, can be made to work positively to both reduce inequality and improve educational achievement (Carnoy, 2005; Carnoy et al., 2007). However, in post-colonial societies like Malawi and to a lesser extent Lesotho, the notion of the western model of the 'school' and within it, the largely age determined 'class', has predominated as a so called functionally adapted system (Parsons, 1983; Little, 2006). And although the western model of the school has been seen to contribute to nation building and national stability during the immediate post-colonial period, the exclusionary tendencies of the 'one size fits all approach' has done little for the millions who have been excluded. Unequal social forms have indeed been replicated in both contexts. HIV is making a difficult situation worse.

\subsection{Definition of ODFL}

The terms open and distance learning have been widely debated in the distance education literature (see for example Rumble (1989) and Lewis (1990) for an early discussion and Harris (1987) for a useful sociological analysis). Perraton defines distance education as 'an educational process in which a significant proportion of the teaching is conducted by someone removed in space and/or time from the learner', and he defines open learning as 'an organized educational activity, based on the use of teaching materials, in which constraints on study are minimised either in terms of access or of time and place, pace, methods of study or any combination of these' (Perraton, 2007:12-13). The concepts of 'openness' and 'distance' in western educational debate are clearly relative. It is argued, particularly by some egalitarians, that it is appropriate for curricula, pedagogy, and forms of educational structure to become more open and as flexible as possible, as this will encourage increased learner autonomy and independence. Advances in telecommunications mean that distances between learners, teachers and educational resources, are being reduced across both time and space. The Internet has done much to re-frame time-space restrictions with respect to distance and educational closure in some societies. However, for the majority of the world's people, residing in low income settings, the Internet is yet to significantly improve the provision of education opportunities. To date the information technology revolution in education has had little impact on most schools in Malawi and Lesotho, where poor infrastructure development and low information technology penetration outside the capital cities is the norm.

\subsection{The Lesotho-Malawi development picture}

Tables 1, 2 and 3 below, present information on some basic development and education indicators for Lesotho and Malawi, by way of providing background and context to the forthcoming discussion. 
Table 1: Lesotho and Malawi - Basic social indicators

\begin{tabular}{|c|c|c|c|c|c|c|c|c|c|c|c|c|}
\hline \multirow[t]{2}{*}{ Country } & \multirow{2}{*}{$\begin{array}{l}\text { Income } \\
\text { classific } \\
\text { ation } \\
\text { Low= } \\
<875 \text { US } \\
\$ \text { pa }\end{array}$} & \multirow{2}{*}{$\begin{array}{l}\text { Popul- } \\
\text { ation } \\
(000) \\
(2005)\end{array}$} & \multicolumn{3}{|c|}{$\begin{array}{l}\text { Life Expectancy } \\
\text { at birth (2005) }\end{array}$} & \multirow{2}{*}{$\begin{array}{l}\text { HIV } \\
\text { Adults } \\
\text { prevale } \\
\text { nce rate } \\
15-49 \\
(2005)\end{array}$} & \multirow{2}{*}{\begin{tabular}{|l|} 
U5 \\
Mort- \\
ality \\
Ratel \\
Rank \\
(2005)
\end{tabular}} & \multirow{2}{*}{$\begin{array}{l}\text { GDP per } \\
\text { capita } \\
\text { Ave. } \\
\text { annual } \\
\text { Growth } \\
\text { rate } \\
1990-2005\end{array}$} & \multirow{2}{*}{$\begin{array}{l}\text { GNP } \\
\text { per } \\
\text { capita } \\
\text { US\$ } \\
2005\end{array}$} & \multirow{2}{*}{$\begin{array}{l}\text { \% Pop } \\
\text { Living } \\
\text { on less } \\
\text { than \$2 a } \\
\text { day } \\
1990- \\
2004\end{array}$} & \multirow[t]{2}{*}{$\begin{array}{l}\text { HDI } \\
2005\end{array}$} & \multirow{2}{*}{$\begin{array}{l}\text { HDI } \\
\text { Rank } \\
\mathrm{N}= \\
177\end{array}$} \\
\hline & & & $M$ & $F$ & $\mathbf{T}$ & & & & & & & \\
\hline Lesotho & Middle $^{1}$ & 1,795 & 42.1 & 42.9 & 42.6 & 23.2 & \begin{tabular}{|l|}
$132 / 57$ \\
\end{tabular} & 2.3 & 950 & 56.1 & 0.549 & 138 \\
\hline Malawi & Low & 12,884 & 46.0 & 46.7 & 46.3 & 14.1 & $125 / 19$ & 1.0 & 160 & 76.1 & 0.437 & 164 \\
\hline
\end{tabular}

Sources: UNESCO (2007) Global Monitoring Report - UNDP (2007) Human Development Report

Table 2: HIVIAIDS

\begin{tabular}{|l|r|r|r|r|r|}
\hline Country & $\begin{array}{l}\text { Population } \\
\mathbf{( 0 0 0 )} \mathbf{2 0 0 4}(\mathbf{2})\end{array}$ & $\begin{array}{l}\text { Adults \& children } \\
\text { Living with HIVIAIDS } \\
\mathbf{( 1 )}\end{array}$ & $\begin{array}{l}\text { Prevalence } \\
\text { (\%) rate (1) } \\
\text { Adults aged } \\
\mathbf{1 5} \text { to 49 }\end{array}$ & $\begin{array}{l}\text { Deaths due } \\
\text { to AIDS (1) }\end{array}$ & $\begin{array}{l}\text { Women aged 15 and } \\
\text { over living with HIV } \\
\text { (1) }\end{array}$ \\
\hline Malawi & 12,608 & 940,000 & 14.1 & 78,000 & 500,000 \\
\hline Lesotho & 1,798 & 270,000 & 23.2 & 23,000 & 150,000 \\
\hline South Africa & 47,208 & $5,500,000$ & 18.8 & 320,000 & $3,100,000$ \\
\hline
\end{tabular}

Sources: (1) UNAIDS (2006) (2) WHO (2006) World Health Report

Table 3: Education access and performance and the Education Development Index (EDI)

\begin{tabular}{|l|l|l|l|l|l|l|l|l|l|}
\hline Country & $\begin{array}{l}\text { EDI } \\
\text { Rank }\end{array}$ & $\begin{array}{l}\text { EDI } \\
\text { Classific } \\
\text { ation }\end{array}$ & EDI & $\begin{array}{l}\text { NER } \\
\text { Primary } \\
\text { (\%) }\end{array}$ & $\begin{array}{l}\text { Primary } \\
\text { completion } \\
\text { rate I } \\
\text { Access to } \\
\text { last grade } \\
\text { (\%) (2002) }\end{array}$ & $\begin{array}{l}\text { Actual } \\
\text { primary } \\
\text { Secondary } \\
\text { transition } \\
\text { rate (2004) }\end{array}$ & $\begin{array}{l}\text { Upper } \\
\text { Secondary } \\
\text { access to } \\
\text { last grade } \\
\text { (\%) }\end{array}$ & $\begin{array}{l}\text { Adult } \\
\text { literacy } \\
\text { rate (\%) } \\
\text { (2000- } \\
\mathbf{2 0 0 4 )}\end{array}$ & $\begin{array}{l}\text { GER } \\
\text { Gender } \\
\text { Parity } \\
\text { Index } \\
\text { (\%) (2002) }\end{array}$ \\
\hline Lesotho & 101 & Medium & 0.824 & 0.871 & 67 & 65.9 & 17 & 82 & 101 \\
\hline Malawi & 112 & Low & $0.734^{*}$ & 0.952 & 73 & 74.3 & 18 & 64 & 96 \\
\hline
\end{tabular}

Sources: UNESCO (2006, 2007) Global Monitoring Report 2007 and 2008

As can be seen from the evidence in Tables 1-3, and from the composite indicator the Human Development Index (HDI) rankings of 149 for Lesotho and 165 for Malawi, both these countries can be considered extremely poor, relative to other states. The HIV infection levels in Malawi and Lesotho increase the scale of the development challenge, impacting severely on the achievement of the EFA project in both countries.

In Malawi the number of orphans was estimated at 650,000 in 2003 rising by an expected $10 \%$ a year $(65,000)$ over the next decade, bringing the expected total to over $1 \mathrm{~m}$ by 2010 (MOE, n.d). In Lesotho it is estimated that around $19 \%$ of all children $(96,000)$ are orphans (NAC, 2005:4).

\section{Who is out of school and who has school failed? The unlucky generations}

In 1962, prior to the establishment of the United Kingdom Open University (UKOU) in 1971 the British social entrepreneur Michael Young wrote a provocative paper which asked the question 'Is your child in the unlucky generation?' (Young, 1962). This paper referred to the children of the post-war baby boom who, due to the restrictive higher education policies of the 1950's-1960's, failed to access higher education and this formed the basis of an

\footnotetext{
${ }^{1}$ Middle income: US\$ 876-10,725
} 
argument for what was to become a state sponsored National Open University - the UKOU. Similarly, during the early post-apartheid period young people who had missed out of schooling (some of whom had deliberately de-linked from school to lead protests against apartheid) were labelled the 'lost generation' until people realised the damage such labelling could do and succeeded in getting the term largely dropped in policymaking. The inclusive EFA policy of the post-apartheid government in South Africa has fortunately been largely successful at improving access to education for those that have been educated post-1994. But the policy has been less effective for those who de-linked and who are still yet to be served by lifelong education policies and programmes in South Africa (Aitchison, 2004). White Paper 6 on inclusive education has lately been introduced in an attempt to redress the situation, but it has only been partially successful. Human resource and capacity challenges are apparently hampering implementation².

The next section provides an indication of the size of the out of school population in Lesotho and Malawi. However, here we are mainly talking about the secondary level. For it is at the secondary level that I believe ODFL holds most promise. However, discussion of noncompletion at the primary cycle is also important particularly in terms of arguments for improved efficiency, redress, and social justice.

\subsection{Out of primary school}

In 2001/2002 it was estimated that 115 million children are out of school globally (UNESCO/UNICEF, 2005). However, calculating and comparing the number of children out of school is not straightforward. Different countries and international agencies use different data sets and methodologies to compile and report figures. Different countries have different definitions of what counts as primary education. The length of the primary cycle can vary from 4 years to 8 years. The length of the compulsory school period also varies. In Lesotho it is 6-12 years, in Malawi it is 6-13 years. The numbers of overage children in a cohort varies with policy, place, and time. Primary age children in pre-primary or secondary schools have not until recently been counted as being in school. Not all countries in the world provide a legal guarantee to free primary education. Neither Lesotho nor Malawi, provide a legal guarantee to free primary education.

The causes of being out of school are also complex. It is apparent such factors as the mother's education, the age at which children commence school, the household levels of income, location (poverty), and the child's residential location (rural or urban), all have bearing on school participation. When children start school late or repeat grades, it increases their chances of dropping out before completing the cycle. Determining who is out of school and why is challenging. The most comprehensive global study we have on the issue is the joint UNESCO-UNICEF report Children Out of School: Measuring Exclusion from Primary Education published in 2005. Regression analysis in this study suggested loosing one or both parents lowered the likelihood of children attending school by $3.6 \%$. Though the way the factor works is highly context dependent particularly in Africa, as the role played by the extended family can be very influential. The level of parental education and the gender of the household head also appear to affect the attendance rates. Children with mothers with low levels of formal education are more likely to be out of school. If the sex of the head of household is male, the children are more likely to be at risk of not attending school (UNESCO/UNICEF 2005:51-52).

\footnotetext{
${ }^{2}$ Welch, T. Personal communication at the SOFIE Research Project launch workshop, September 2007
} 


\subsubsection{Lesotho}

Lesotho introduced Free Primary Education in January 2000 (MOE, 2001). In 1999, only $45.5 \%$ of the full time school age population (6-24 years) in Lesotho were actually in school, and one third of Basotho youth and adults were illiterate (MOE, 2005:89). In 2005 the total primary enrolment was 422,278 (212,683 boys and 209,595 girls). $33 \%$ of these children were over-age (6-12 years) or 141,275 children. 55,000 new children entered the primary schools in 2005 (UNESCO 2007:282). The Net School Attendance ratio (1996-2005) is recorded by UNICEF as $62 \%$ for males and $69 \%$ for females. It is estimated using administrative data that $63 \%$ of primary school entrants complete the primary cycle (UNICEF 2007:119). This suggests that about 33\% of children are out of school in Lesotho. The UNESCO Global Monitoring Report for 2008 provides data which estimate the total number of children believed to be out of school as 41,000 of which $40 \%$ are girls - see Table 4 below.

Table 4: Out of school primary children

\begin{tabular}{|l|l|l|l|l|}
\hline \multirow{2}{*}{ Country } & \multicolumn{2}{|c|}{1999} & \multicolumn{2}{c|}{ 2005 } \\
\cline { 2 - 5 } & Total (000) & \% F & Total (000) & \% \\
\hline Lesotho & 139 & 45 & 41 & 40 \\
\hline Malawi & 23 & 100 & 113 & 27 \\
\hline
\end{tabular}

Source: UNESCO (2007:291) EFA Global Monitoring Report 2008

There were 1,419 primary schools in Lesotho in 2005. Significantly, $29 \%(122,769)$ of enrolled children were orphans (57\% had lost a father, $19 \%$ had lost a mother and $23 \%$ (over one-fifth) had lost both parents. What is particularly hard for orphans is that 'The traditional system of inheritance tends to displace children whose parents have died, from inheriting their parent's estate' (NAC, 2007: xi). Importantly, these primary enrolment figures are down on the 2003 figures, when the MOE recorded 429,720 enrolments (MOE, 2005). See also Nyabanyaba (2008) for further details.

\subsubsection{Malawi}

Malawi introduced Free Primary Education in 1994. In 2005, 648,000 new entrants enrolled in the primary schools. The Net School Attendance ratio over the period 1996-2005 is recorded by UNICEF as $80 \%$ for males and $84 \%$ for females. Using the Net Attendance Ratio it is estimated that about $20 \%$ of primary school aged children are out of school in Malawi (UNICEF 2007:119; Streuli and Moleni, 2008:11). Table 5 below gives details of the Net Attendance Ratio for Malawi primary children.

Table 5: Malawi: Net Attendance Ratio

\begin{tabular}{|c|c|c|c|}
\hline $\begin{array}{c}\text { Background } \\
\text { Characteristic }\end{array}$ & \multicolumn{3}{|c|}{ Net Attendance Ratio } \\
\hline & Female & Male & Total \\
\hline Location & & & \\
\hline Urban & 89.4 & 89.0 & 89.2 \\
\hline Rural & 83.0 & 78.7 & 80.9 \\
\hline Wealth quintile & & & \\
\hline Lowest & 75.0 & 71.8 & 73.5 \\
\hline Highest & 93.8 & 92.2 & 93.0 \\
\hline TOTAL & & & \\
\hline
\end{tabular}

Source: National Statistical Office and ORC Macro (2005:17) 
The UNESCO Global Monitoring Report for 2008 estimates that 113,000 children were out of primary school in 2005 of whom $27 \%$ were female - see Table 4 above. UNICEF (2006) using administrative data for their 2007 State of the World's Children report estimate only $44 \%$ of primary school entrants in Malawi reach Grade 5. While the latest UNESCO Global Monitoring Report (2007:306) reports the Survival Rate to the Last Grade as being even lower at just 34\% - using 2004 data.

\subsection{Out of secondary school}

Access to secondary education in Lesotho and Malawi is also poor, with only about $35 \%$ gaining access in Lesotho and 33\% doing so in Malawi. Hence, about two-thirds (66\%) of those eligible for secondary education in both countries are being denied secondary schooling. By comparison, South Africa's provision is much better, with only $12 \%$ denied access. Secondary education systems in Malawi and Lesotho also display high levels of inefficiency, wastage, and inequity. In Malawi although some $87 \%$ of those who graduate at the end of the primary cycle transit to the first grade of lower secondary, only $18 \%$ of that number enter the final secondary grade. From the data available, it can be estimated that there are at least 1.2 million secondary level children 'out of secondary school' in Malawi and Lesotho combined. Table 5 below gives some data on the numbers of children who are pushed out of secondary school.

Table 6: Secondary school push out - Numbers of children failing to complete secondary education

\begin{tabular}{|c|c|c|c|c|c|c|}
\hline \multirow[t]{2}{*}{ Country } & \multirow[t]{2}{*}{$\begin{array}{l}\text { Age } \\
\text { group }\end{array}$} & \multirow{2}{*}{$\begin{array}{l}\text { School age } \\
\text { population } \\
2004\end{array}$} & \multicolumn{2}{|c|}{$\begin{array}{c}\text { Total Enrolment } \\
2005 \\
\end{array}$} & \multirow[t]{2}{*}{$\begin{array}{l}\text { Estimated out } \\
\text { of school youth }\end{array}$} & \multirow{2}{*}{$\begin{array}{l}\text { \% Out of } \\
\text { school of } \\
\text { total eligible }\end{array}$} \\
\hline & & & Total & $\% \mathrm{~F}$ & & \\
\hline Lesotho & $13-17$ & 244,000 & 94,000 & 56 & 155,000 & 61 \\
\hline Malawi & $12-17$ & $1,822,000$ & 515,000 & 45 & $1,049,000$ & 72 \\
\hline Total & & $2,066,000$ & 609,000 & & $1,457,000$ & 71 \\
\hline
\end{tabular}

Source: UNESCO (2006) Global Monitoring Report 2007

\subsection{Adult literacy}

The total number of illiterate adults in the two countries is estimated at $2.3 \mathrm{~m}(182,000$ in Lesotho and $2.1 \mathrm{~m}$ in Malawi). Over a quarter of the adult population are regarded as officially 'illiterate'. Despite a rising population, both countries have made progress with reducing youth illiteracy. Malawi has reduced the total numbers of youth illiterates down from 655,000 in 1990 to 525,000 in 2004 . However, overall the total number of illiterate adults and youth is still substantial and was estimated to be around 2.8 million according to 2004 data (the latest available).

Table 7: Adult literacy 1990-2004/2015

\begin{tabular}{|c|c|c|c|c|c|c|c|c|c|c|c|c|c|c|c|}
\hline \multirow[t]{3}{*}{ Country } & \multicolumn{9}{|c|}{ Adult Literacy Rate 15 and over (\%) } & \multicolumn{6}{|c|}{ Adult Illiterates (15 and over) } \\
\hline & \multicolumn{3}{|c|}{1990} & \multicolumn{3}{|c|}{2004} & \multicolumn{3}{|c|}{ Projected 2015} & \multicolumn{2}{|l|}{1990} & \multicolumn{2}{|l|}{2004} & \multicolumn{2}{|c|}{ Projected 2015 } \\
\hline & $\mathbf{T}$ & $\mathbf{M}$ & $\mathbf{F}$ & $\mathbf{T}$ & M & $\mathbf{F}$ & $\mathbf{T}$ & $\mathbf{M}$ & $\mathbf{F}$ & $\begin{array}{l}\mathrm{T} \\
(000)\end{array}$ & $\% F$ & $\begin{array}{l}T \\
(000)\end{array}$ & $\% \mathrm{~F}$ & $\begin{array}{l}T \\
(000)\end{array}$ & $\% \mathrm{~F}$ \\
\hline Lesotho & 78 & 65 & 89 & 82 & 74 & 90 & - & - & - & 183 & 29 & 182 & 32 & - & - \\
\hline Malawi & 52 & 69 & 36 & 64 & 75 & 54 & 79 & 83 & 75 & 2,429 & 69 & 2,133 & 66 & 1,851 & 62 \\
\hline
\end{tabular}

Source: UNESCO (2006:234-237) EFA Global Monitoring Report 2007 and UNESCO (2007: 258) Global

Monitoring Report 2008 for the Projected 2015 column 
Table 8: Youth literacy and illiteracy rates 1990-2004 - with partial 2015 projections

\begin{tabular}{|c|c|c|c|c|c|c|c|c|c|c|c|c|c|c|c|}
\hline \multirow[t]{3}{*}{ Country } & \multicolumn{9}{|c|}{ Youth Literacy Rate (15-24 years) (\%) } & \multicolumn{6}{|c|}{ Youth Illiterates (15-24 years) } \\
\hline & \multicolumn{3}{|c|}{1990} & \multicolumn{3}{|c|}{$2000-2004$} & \multicolumn{3}{|c|}{ Projected 2015} & \multicolumn{2}{|l|}{1990} & \multicolumn{2}{|c|}{ 2000-2004 } & \multicolumn{2}{|c|}{$\begin{array}{l}\text { Projected } \\
2015\end{array}$} \\
\hline & $\mathbf{T}$ & M & $\mathbf{F}$ & $\mathbf{T}$ & M & $\mathbf{F}$ & $\mathbf{T}$ & M & $\mathbf{F}$ & $\mathrm{T}(000)$ & $\% \mathrm{~F}$ & $\mathrm{~T}(000)$ & $\% F$ & $\mathrm{~T}(000)$ & $\%$ \\
\hline Lesotho & 87 & 77 & 97 & - & - & - & - & - & - & 38 & 12 & - & - & - & - \\
\hline Malawi & 63 & 76 & 51 & 76 & 82 & 71 & 90 & 89 & 91 & 655 & 68 & 525 & 62 & 369 & $\begin{array}{l}4 \\
5\end{array}$ \\
\hline
\end{tabular}

Source: UNESCO (2006: 236-237) EFA Global Monitoring Report 2007 and UNESCO (2007) Global Monitoring Report 2008 for the projected figures

Further, the very high levels of drop out/non completion from the primary stage and low access to the secondary level are combined with poor monitoring and availability of information. For example, it can be noted MOEVT policy in Malawi requires all schools to maintain student attendance registers but this is not enforced, and in any case many schools do not receive official registers on an official basis (MOEVT, 2006:12).

\section{Theories of inclusion/exclusion}

All political and social doctrines serve interests. The issue is whether those interests are particular or universal (Byrne, 2005:32)

This section reviews some of the theories of inclusion and exclusion with respect to education. Theories of social exclusion/inclusion are generally derived from and underpinned by much older $17-19^{\text {th }}$ century (largely European) theories of political philosophy. Byrne (2005) argues that over the last two-three centuries three different meta theories have coexisted and underpinned debates about inclusion/exclusion (and equality/inequality): (i) Classical liberalism with its emphasis on possessive individualism stresses negative liberties of the self (see Swift (2006) for an explanation of the concepts of positive and negative liberties), the importance of the market and the limited, almost residual role of the collective sphere; (ii) traditional Conservatism typified by 20th century Catholicism, emphasises the integration of the individual into a traditionally legitimised social order; and (iii) the radical (yet largely failed) socialist Marxist project, which sought to eliminate inequality through the transformation of capitalism into socialism. Economically such theories are related to classical economics (Utilitarianism), the neo-liberal market orthodoxy and more recent forms of third way social democratic thinking with an emphasis on egalitarianism, global social justice and the spread of universal human rights (Byrne, 2005; Pogge, 2002). The belief that state sponsored education and welfarism could, and indeed should, challenge and change persistent and deeply entrenched inequality and exclusion, is in many ways a quite recent (post-Second World War) phenomenon. The MDG/EFA movement represents the latest stage in an increasingly global compact to eliminate poverty and the worst forms of oppression, exploitation and persistent exclusion (Held, 2004; Unterhalter 2007).

From a sociological perspective, the liberal-conservative view sees schools as largely functionally adapted to their socio-economic environment and thereby as positive forces that effectively evolve and promote positive change gradually. In that sense the school represents a stable, homeostatic, well-adapted structure (see for example Parsons, 1983). In this view, exclusions are unavoidable, temporary aberrations that can at some point be incorporated with appropriate structure-process modifications. The fact that such exclusions resolutely persist and in some instances expand, as potentially in the case of HIV related exclusion, might be seen as part of a new 'violence of silence'. In contrast, more radical Marxist and some aspects of recent post-modern thinking, regard schools more as agents of control and reproduction (of exclusion and inequality). Exclusions seen through this lens are 
regarded as avoidable phenomena that result from inadequately mediated, or unresolved and persistent conflicts of interest. But schools are also in some respects causative of such conflicts and violence acting as mechanisms control, surveillance and sanctioned exclusion, which work to maintain the status quo of the existing 'order liberalism', to the advantage of those currently in school (see for example Harber, 2004).

It can be argued that the largely functionalist/structural functionalist analysis of schooling, which has taken place over the last 60 years in most western systems of liberal education, has pursued a progressively widening process of analysis, critique and gradualist adaptation that has sought to systematically incorporate and include the excluded, through piecemeal, gradualist accommodation, rather than wholesale systematic reform. If we take as an example the history of the development of Special Needs Education (SEN), Clough and Corbett (2000) trace the evolution of the inclusive education movement through a series of five complimentary and mutually reinforcing stages or perspectives. They begin with an early psycho-medical perspective which developed in the 1950's. This is followed by a move to a sociological critique of the psycho-medical model in the 1960's, which in part draws on the New Sociology of Education (NSE) (Young, 1971). In the 1970's we see the emergence of a strongly curricular approach in which curriculum projects and teacher development are used to influence and promote new ideas about SEN. Then in the 1980's the SEN approach develops using wider school improvement strategies. Finally, in the 1990's, they argue we see the emergence of post-modern disability studies critiques. Such a staged development corresponds to the Special, Integrative and Inclusive stages in policy framing or as the 'era of institutions'; the era of de-institutionalisation' and the 'era of community membership'. Table 8 summaries this development (Clough and Corbett, 2000).

Table 9: Evolution of notions of Exclusion-Inclusion with respect to Education Provision for All

\begin{tabular}{|c|c|c|}
\hline $\begin{array}{l}\text { Predominant Sociological } \\
\text { I Political view }\end{array}$ & SEN perspective & $\begin{array}{l}\text { Interpretation } \\
\text { Institutional perspective }\end{array}$ \\
\hline $\begin{array}{l}\text { Modern } \\
\text { Liberal Functionalist }\end{array}$ & $\begin{array}{l}\text { Psycho-medical } \\
\text { A system of broadly medicalized ideas which } \\
\text { saw the individual as somehow being in deficit } \\
\text { and as such assumed a need for special } \\
\text { education for those individuals }\end{array}$ & $\begin{array}{l}\text { Special } \\
\text { Era of institutionalisation - } \\
\text { separation } \\
\text { SEN Children seen as } \\
\text { 'Them' }\end{array}$ \\
\hline $\begin{array}{l}\text { Modern } \\
\text { Marxist-Structuralist }\end{array}$ & $\begin{array}{l}\text { Sociological critique } \\
\text { A critique of the psycho-medical model - } \\
\text { disability and special need as social } \\
\text { construction } \\
\text { Curricular focus } \\
\text { Focus on how curriculum meets and to some } \\
\text { extent creates learning difficulty }\end{array}$ & $\begin{array}{l}\text { Integrative } \\
\text { Era of } \\
\text { de-institutionalisation } \\
\text { Recognition of SEN } \\
\text { children positioned as } \\
\text { 'The Other' }\end{array}$ \\
\hline $\begin{array}{l}\text { Modern } \\
\text { Structural-Functionalist }\end{array}$ & $\begin{array}{l}\text { School improvement } \\
\text { Importance of systematic organisation in the } \\
\text { pursuit of truly comprehensive schooling }\end{array}$ & $\begin{array}{l}\text { Integrative } \\
\text { Era of } \\
\text { de-institutionalisation }\end{array}$ \\
\hline Post-Modern & $\begin{array}{l}\text { Critique of disability } \\
\text { Perspectives often from outside 'education' } \\
\text { which articulate a overtly political response to } \\
\text { the exclusionary effects of the psycho-medical } \\
\text { model - A re-emphasis on understanding } \\
\text { differential power relations, conflict and the } \\
\text { importance of human agency }\end{array}$ & $\begin{array}{l}\text { Inclusive } \\
\text { Era of community } \\
\text { A move the regard all } \\
\text { children/learners as } \\
\text { 'Us' }\end{array}$ \\
\hline
\end{tabular}

Developed from Clough and Corbett (2000: 7-32)

For another recent review of the development of inclusive (special) education with an international, including an EFA perspective, see Florian (2007). 


\section{Some cautions}

The staged development as described by Clough and Corbett presents a rather deterministic process that needs a word of caution. For example, in their discussion of inclusion-exclusion Sayed and Soudien (2003) make a number of caveats about inclusion/exclusion debates which are relevant to this paper. To paraphrase Sayed and Soudien, first, they argue inclusion often proffers a strongly normative stance - to be 'included' is 'good', while to be 'excluded' is 'bad'. However, it may be that for those out of school in low-income, high HIV incidence settings, exclusion (albeit temporarily) may be vitally important to the maintenance of any kind of sustainable family structure. Affected youth may prefer to remain excluded from schools in order to deliver the love, care and support affected relatives desperately need. Secondly, inclusion operates from a 'principle of normalisation', in that to be included is the 'ideal state' while to be excluded is in some way 'abnormal', with people being seen as in some way deprived of key entitlements. Evidence for this view was found in and earlier study we carried out in Mozambique and South Africa (Pridmore and Yates, 2006). But a 'normalization framing' can result in policy designed merely to overcome deficits as with school feeding programmes, bursary schemes, and various forms of temporary subsidy and other response welfare. Such actions can thus fail to adequately problematise cause-effect relationships, such that the complex factors which give rise to observed inequities remain unchallenged, ill understood and invariably unchanged, long-term. Social exclusion can also become a universal discourse which applies only to amorphous groups and thus it fails to individualise and personalise impact. Such a discourse assumes a 'pathology of personal and group failure' which tends to position those involved as the 'other', ultimately blaming them as victims. Fourth, Sayed and Soudien argue the discourse of inclusion-exclusion can fail to sufficiently understand, appreciate or specify the nature of the complex relationships and intersections between social differences such as: race, class, gender, age, disability, health status etc., and how these intersect with the economic, social and cultural spheres in relational and determining ways (Sayed and Soudien, 2003).

\section{The notion of exclusion - Why is it important to theorise it?}

The problem for the forcibly de-schooled - those who are pushed, pulled or by any force of circumstance, required to de-link from conventional schooling, is that they represent a form of under-development. A category that represents a dis-economy in this globalising international era (see for example Hoogvelt (2001) particularly chapter 8 Africa: Exclusion and the containment of anarchy). Such people are not a cheap 'reserve army' in any postMarxian sense that can serve in the tobacco or sugar cane fields of Malawi or the Chinese sponsored textile factories of Lesotho competitively, but a surplus with no and indeed a negative social credit. People in this position rarely figure highly in the state demographic and economic bank balance. In this sense, it is a short step to significant disempowerment and serious loss of citizenship and the basic rights states are supposed to guarantee people who reside within their borders. Exclusion in this sense, is not far from creating the 'useless surplus' Byrne (2005) warns about above.

\section{Policies}

Ideas about open and distance learning in both Malawi and Lesotho are scattered in a number of different policy documents. This section of the paper begins to identify and review briefly what exists in mainstream education policies and what is said in the non mainstream - e.g. in non-formal education, ICT and other supplemental areas of education policy making in Malawi and Lesotho. 


\subsection{The formal education system}

Neither Lesotho nor Malawi have specific policies on open or distance education. This is somewhat surprising, as both countries have two of the oldest systems of distance education in Africa: Lesotho College of Distance Education (LDTC) and the Malawi College of Distance Education (MCDE). This absence of policy seems indicative that both Ministries of Education have downgraded the importance of their distance learning systems. They have done this in the case of Malawi, by co-opting and mainstreaming the former MCDE Study Centers to become more formal Day Community Secondary Schools (DCSS) and in the case of Lesotho, by leaving LDTC to respond mainly to the adult literacy challenge (albeit with the support of a Non-formal Education Division within the Ministry of Education) combined with small scale efforts to serve out of school youth with basic and secondary education. What statements that are made about ODFL are integrated into the mainstream education plans for the sub sector levels at primary, secondary, technical-vocational, tertiary or come under other areas, some of which are cross cutting for example, non formal education, ICT policy, and Inclusive Education policy. There are rather vague statements about the importance of distance education for example the Malawi Education Sector Plan comments 'Strengthened liaison with the Distance Education college will lead to expansion of secondary level education to out of school students' (MOEVT, 2006). But there is little clarity on why this is to happen and to what end. Interestingly, the Malawi plan suggests it has 16 open schools as part of the government day system - but a definition of what is meant by 'open school' in this context is not provided.

All this is indicative of a 'thin form of integration'. ODL is as yet only thinly integrated into the mainstream. What is perhaps needed in a lifelong learning HIVIAIDS context is a much 'thicker integration'. A form of integration which is much more sensitively tuned to the specific contexts, circumstances, and needs of those presently excluded from learning throughout life.

\subsection{The non-formal education system}

\subsubsection{Lesotho: Non-formal Education Policy}

The main policy document covering the operation of ODFL in Lesotho is the Draft Policy Document on NFE in Lesotho 2001. It is claimed in the document that the policy was arrived at through a countrywide consultative and participatory process (MOE, 2001:6-16). From the description provided of the process given in the document, there is evidence that the process was indeed consultative. That said, the Lesotho non-formal education policy is yet to be formally ratified. Key stakeholders here argue that an NFE policy is necessary for a number of reasons not least because of the need to coordinate the plethora of activities which have arisen in the face of high wastage and inefficiency and the lack of response to the growing number of out of school and at risk children. This is recognised in part, to be a result of the shortcomings of the mainstream education sector (drop-out, need for lifelong continuing education, high levels of functional illiteracy, out of school youth etc). There remains a particular urgency to identify, prioritise and effectively respond to those in 'most need'. Institutions like Lesotho Association for Non-formal Education (LANFE), the Lesotho Distance Teaching College (LDTC), the Institute of Extra Mural Studies (IEMS) at the National University of Lesotho and the NFE Inspectorate (established in 1993) in the MOE, have all played important roles in pioneering early responses and provision. Table 9 below lists the national goals for NFE in Lesotho. 


\begin{tabular}{|l|}
\multicolumn{1}{|c|}{ Lesotho - National Goals for NFE } \\
\hline 1: to provide by the year 2009, literacy and functional literacy education to about $30 \%$ of the \\
present $57 \%$ functionally illiterate adults and youths \\
\hline 2: to eradicate ignorance and poverty through the provision of vocational /income generation \\
skills aimed at self employment and job creation within a period of 10 years, as a determined \\
starting point range \\
\hline 3: to provide productive occupational and managerial skills to Basotho people for the purpose of \\
promoting and enhancing efficiency of high quality work \\
\hline 4: to sustain environmental and social conditions which enhance the quality of life produce \\
responsible citizenship and an ordered society \\
\hline 5: to enhance self reliance and self sufficiency art the individual and national levels so as to \\
reflect our cultural heritage and national aspiration in the process of industrialization \\
\hline 6: To promote creativity in the provision of life skills so as to enhance full participation in societal \\
development \\
\hline 7: to guarantee healthy living and the reduction of mortality rate among the Basotho people \\
through the provision of NFE programmes that address primary health care delivery system, \\
eradication of diseases and the creation of awareness about HIV and AIDS \\
Source: MOE (2001: 23-24)
\end{tabular}

\subsubsection{Malawi: Non-formal Education (NFE) Policy}

NFE in Malawi is spread across a number of different ministries and hence suffers from an inevitable a lack of focus and coordination. The Ministry of Education and Vocational Training (MOEVT) does not formally coordinate NFE policy, though it recognises the importance of such activities and its relevance to its own planning and analysis for considering the overall picture of pupil attainment. As we have seen above, over $50 \%$ of those who enter the Malawi primary system leave by the end of Standard 4. At the secondary level, MOEVT recognises there could be greater clarity and better coordination in terms of improved inter ministerial responsibility for providing NFE, and aims to strengthen communications with other Ministries which manage complementary and alternative forms of education and training (MOEVT, 2006:11-12). The government also recognises the importance of the Malawi College of Distance Education (MCDE) as an out of school youth secondary education provider. It intends to incorporate the MCDE strategic plan into the main National Education Sector Plan (NESP).

\subsection{ICT policies}

ICT policies are clearly important for opening education systems and closing educational distances in both countries. In both Lesotho and Malawi the aim appears to be to put in place policies and programmes designed to try to leapfrog over the industrial era, into a agro-information era, driven in the case of Lesotho, by a strongly neo-liberal discourse which pays little heed to the needs of those who are out of the mainstream, while in Malawi the discourse is a softer variant, offering statements aimed at rural inclusion and village development to counterbalance the globalising ambitions of an information economic order.

\subsubsection{Lesotho: National ICT Policy}

The Government of Lesotho (GoL) released its first National ICT policy in 2005. The vision is 'To create a knowledge-based society fully integrated into the global economy by 2020' (GoL 2005:18) The primary aim is to transform Lesotho into an ICT literate, knowledge based society, which is capable of both producing as well as using ICT based products and services in pursuance of a more information driven economy. Education institutions are encouraged to make better and more effective use of ICT to improve the quality of teaching and learning and extend access through increased use of distance and electronic virtual learning provision. Education institutions must ensure ICT literacy is part of the core 
curriculum. There are also sections devoted to health and gender and youth. In both of these areas, it is agued ICT have an important role in delivering improved service delivery, information and equity. Further, it is believed that such technologies can work to reach out to youth and women to include them in the development process and help them develop new skills which will allow them to play a more active role in the future national economy (GoL, 2005:46). For its part, government will work towards creating job opportunities in the ICT area encouraging in particular, partnerships between state institutions and the private sector in the ICT area. Policy effort is directed towards using ICTs to facilitate education and lifelong learning in both the formal and vocational sectors and to supporting the private sector in its delivery of on the job training and retraining programmes (GoL, 2005). It is clear that the GoL advocates an integrationist approach through its ICT policy.

\subsubsection{Malawi National ICT Policy}

Malawi published its first national ICT policy in June 2003. The focus for the Malawi government is with promoting an enabling environment for ICT development and utilisation and the improved delivery of goods and services in key sectors (key sectors include both education and health). The aim is move Malawi from a primarily agricultural economy, to an information-rich knowledge based economy' (GoM, 2003a:9). It is recognised that this requires an ICT aware and literate society that can take advantage of ICTs and thereby benefit from current globalisation and liberalisation processes. The discourse has a strong neo-liberal tenor, which prioritises market oriented objectives, although there are a number of more sensitive references to the opportunity to also achieve greater social justice and equity. For example, in the list of objectives there are references 'To improve the ICT infrastructure especially for the rural areas'. This includes the development of a village information and communications infrastructure $(\mathrm{VICl})$ and the facilitation of access to ICT products and services to the underprivileged including establishing multi-purpose community information centres and the delivery of telemedicine (GoM, 2003a:9-13). With respect to education, the objective is far reaching aiming 'To transform the Malawian educational system using ICTs with the aim of improving accessibility to educational resources and facilities; the quality of education and the relevance of educational services and output to development needs of Malawi' (GoM, 2003a:11). The emphasis is on both the expansion of service delivery particularly at the primary and secondary levels and with improving the quality and efficiency of the sector operations. The aim is to introduce computer lessons and promote ICT literacy in schools. There is one brief reference to include ICT promotion through informal provision and one assumes this is aimed at those students who remain out of school. With regard to information services, it is 'To strengthen national information resource centres such as libraries and national Archives and for communities - the government shall promote community access to ICTs in order to speed up the development and utilization of ICTs within communities' (GoM, 2003a:11). The government also wishes to use ICTs to further decentralise the provision and use of government services and operations.

\subsection{HIV and AIDS policies}

\subsubsection{Lesotho: National AIDS Policy}

The estimated prevalence of HIVIAIDS among adults in Lesotho is $23.2 \%$. 266,000 adults and 16,000 children under 14 years of age are infected (NAC, 2007:2). This creates a high disease burden and has a severe impact on development processes among citizens. Among the key drivers of the epidemic are believed to be poverty and food insecurity, underemployment, alcohol and drug abuse, gender inequality and gender-based violence, migrant labour and multiple sex partners and intergenerational sex often involving transactional sex (NAC, 2007: ix-x). Under such circumstances, being out of school significantly increases young people's chances of being exposed to HIV. The country has a 
national 'Know your HIV Status campaign' in which it is expected that all citizens above the age of 12 years are expected to know their HIV status by 2007. Locally, we spoke to informants who did not feel this target was realistic. It is likely to be missed. HIV results in increasing numbers of girls being kept out of school as care-givers. 'HIVIAIDS has forced the girl children to assume the care role that has compromised educational and career opportunities' (NAC, 2007:10).

Governments recognise that it is through the educational empowerment of children, that the best future for a HIV free society exists. Consequently, all children whether they are inside or outside schools need access to information on sexuality that will empower them and enable them to protect themselves from HIV infection, abuse and any infringement of their rights (NAC, 2007: 37-38). ODFL may be able to play a useful complementary role to that of the formal education system in this regard. As such, not only can ODFL programmes help deliver information, education, and training directly to children, they can also work to ensure service professionals including police, health workers and social workers, are trained to provide the best services possible. Spotting abuse or vulnerability and responding appropriately is an important step in the development process.

\subsubsection{Malawi National AIDS policy}

The Malawi National HIVIAIDS Policy was published in June 2003. It is a well written document that addresses many of the complex issues associated with the diagnosis, prevention, treatment, care, support and management of the effects of HIVIAIDS in the country. The policy is based on seven key principles: (i) political leadership and commitment; (ii) multi-sectoral approach and partnerships; (iii) public health approach (iv) promotion and protection of human rights; (v) greater involvement of people living with HIVIAIDS; (vi) good governance, transparency and accountability; and (vii) scientific and evidence based research. These seven principles provide the basis for an integrated national response. The policy and its implementation are coordinated by the National AIDS Commission (NAC), which is responsible to the Office of the President and the Cabinet. The policy requires the government to devote at least $2 \%$ of the national budget to fight HIVIAIDS. Further, the policy states 'Government ministries, departments and district and city assemblies, shall provide resources amounting to at least $2 \%$ of their budgets for HIVIAIDS activities' (GoM, 2003b:9). Prevention, particularly for those out of school, is heavily dependent on the promotion of behaviour change and here the mass media, supported by interpersonal communication, are seen as vital channels. It is recognised however, that information and education provision alone will not sustain lifelong behaviour change and that any programmes must be complemented by services which help to develop motivation and support, build skills to practice new behaviours and promote enabling environments to facilitate sustainable change (GoM, 2003b:10).

Understandably much of the document provides policies to guide many of the medical and more scientific aspects of the HIV challenge. Much less attention is given to the management and mitigation of the social issues associated with the epidemic. The Human Rights chapter (Chapter 4) and the Chapter on the Protection, Participation and Empowerment of Vulnerable Populations (Chapter 5) are useful, however, they primarily place the burden of care and responsibility on reconstructed family structures and the formal schooling system. It is in these chapters that the issues associated with out of school youth, orphans and other vulnerable groups are addressed. For example, 'Government shall ensure that orphans are not denied access to primary education, including by virtue of their inability to pay....Government and partners shall ensure that child headed households are supported in order to safeguard the best interests of children' (GoM, 2003b:20). These policies are however further complemented by some strong statements which support the development of the national youth service including youth counselling, e.g. 'Government and institutions providing education and youth services shall provide multi-purpose youth centres to ensure the well being and development of young men and women while at the same time 
protecting them from HIV and other STI's' (GoM, 2003b:21). These chapters also carry a strong gender focus, particularly with regard to ensuring better personal security, labour protection, and inheritance and property rights.

Finally, government makes a pledge to mainstream HIVIAIDS into all strategies and programmes designed to address poverty reduction, which indicates a strong desire to link activities back to the poverty reduction effort, including making connections to regional development bodies like the Southern African Development Community (SADC) and the International Organisation on Migration (IOM) (GoM, 2003b:23).

\subsection{Other policies}

\subsubsection{Malawi Policy on Teenage Pregnancy and School Re-entry}

It is clear that in many countries, teenage pregnancy acts to deny a number of the girls and boys their education. Under such circumstances basic rights to universal education can be infringed. In Malawi both boys and girls are denied access to education for one year following pregnancy, although in practice the full year of exclusion rarely applies to the boys concerned. Re-admission after pregnancy, can problematic for many girls in African contexts, not least because their new status, maturity and responsibilities for the child; but also because of the potential for stigma, prejudice or inflexible attitudes. Although a readmission policy has been in place since 1993 in Malawi, it was reported that many headteachers continue to deny girls access (though less so for boys as noted above). Recently the GOM MOEVT clarified its policy to try to ensure more of the young people affected are allowed back to school after one year. Although entry is often into another school, other than the one where the pregnancy occurred. The opportunity is given once in a child's education cycle (for both boys and girls). There is however, no reference to any continued educational provision while the children are away from school during the period of the pregnancy. This is one area where governments could take education and provide ODFL courses to those temporarily excluded to ensure they don't fall behind in their studies.

\section{Conclusion and way forward}

Obtaining accurate and detailed statistics for the numbers of children out of school is complex and difficult. If we are to understand the barriers to accessing conventional schooling for young people affected by HIV and AIDS more detailed work needs to be done to better understand patterns of enrolment, attendance and completion and how HIV and AIDS impact on these aspects of schooling. Who enrols and for how long, who completes and who does not and why, are all ill understood questions in both Lesotho and Malawi. It will be important that this research study helps to develop a deeper understanding of the numbers, characteristics, and nature of the children who are out of school in the two study countries and particularly those affected by HIV and AIDS.

With regard to the initiatives and structures that are in place to deliver education to young people, we have seen that both Lesotho and Malawi do not have separate policies for ODFL provision or for the education of out of school youth. In Malawi, this group is, in part addressed by the activities of the Distance Education College (DEC) but as the DEC does not to date appear in the National Education Sector Plan, the needs of the out of school are mostly assumed to be covered by Ministries of Youth and Sport or/and Ministry of Women and Child Development. In contrast, the Lesotho MOE approach is more coherent as the MOE has created a separate NFE policy aimed at out of school people. Both countries also rely on the Health Ministry, multi-media, and NGO activities to provide support. There is a need to undertake more inter-ministerial policy analysis to ascertain levels of consistency between the different Ministry policies and to assess how far they are working together to achieve stated goals effectively. It will also be important to understand better what kind of 
ODFL response would be of most help to children under strain from HIV and AIDS related maladies.

The African Development Bank (ADB) is currently supporting a three-year project of the Southern Africa Development Community (SADC) to develop capacity in open and distance learning in the region. The first stage of this project is to support SADC member states including Lesotho and Malawi to develop ODL policies where they are lacking. This project has relevance to this research and the progress of the SADC project is being followed.

The lack of an enabling policy framework to harness both conventional and distance forms of education training and lifelong learning across different Ministries, may well be one of the key factors holding back the successful integration and inclusion of marginalised citizens, including youth affected by HIV and AIDS. The World Development Report (WDR) (2005) recently recommended the creation of a 'youth lens' to develop policies for the five phases most affecting the development of human capital. These are: (i) continuing to learn; (ii) starting to work; (iii) developing a healthy lifestyle; (iv) beginning a family, and (v) exercising citizenship. The WDR 2006 recommended countries attend to three key issues here: better coordination and integration with national policy, stronger voice, and more evaluation (World Bank, 2006).

Both countries though actively debating issues of inclusive education particularly with regard to disability and special needs education do not yet have specific policies on inclusive education, and this would appear to be an area for future development.

Finally, it is also important to consider how far policies remain at the level of symbolism rather than action, so that they both fail to adequately regulate procedures or successfully challenge and change persistent inequality through new initiatives. It is often asserted that concepts like 'strong political will' should ensure both state action and systematised charity are mutually complementary if inequality is to be effectively addressed. But key change concepts like 'strong political will' as yet remain under theorised (Little, 2008 forthcoming). Theorising political will and deepening our understanding of how such will work to help achieve quality education for all in Malawi and Lesotho, is a key issue for this research. It is through proactive and continuous policy development and the testing and scaling new initiatives that work, that the situations of those affected by HIV and AIDS will be positively addressed. 


\section{References}

AITCHISON, J. (2004) Lifelong learning in South Africa: dreams and delusions. International Journal of Lifelong Education, 23, 517-544.

APPLE, M. W. (1982) Cultural and Economic Reproduction in Education : Essays on Class, Ideology, and the State. London, Routledge \& Kegan Paul.

BOURDIEU, P. and PASSERON, J.-C. (1977) Reproduction in Education, Society and Culture. London, Sage Publications.

BOWLES, S. and GINTIS, H. (1976) Schooling in Capitalist America : Educational Reform and the Contradictions of Economic Life. New York, Basic Books.

BUTCHER, N. (2005) SADC Technical Committee on Distance Education: Lesotho, Tunis, African Development Bank. Background Paper prepared for the SADC/ADB ODFL Capacity Building Project Identification Mission 2005, mimeo.

BYRNE, D. (2005) Social Exclusion. Maidenhead, Open UP.

CARNOY, M. (2005) Cuba's Academic Performance in Comparative Perspective. Comparative Education Review, 49, 230-261.

CARNOY, M., GOVE, A. K. \& MARSHALL, J. H. (2007) Cuba's academic advantage: why students in Cuba do better in school. Stanford University Press.

CLOUGH, P. and CORBETT, J. (2000) Theories of Inclusive Education: A Students' Guide. London, Paul Chapman.

FLORIAN, L. (2007) The SAGE Handbook of Special Education. London, SAGE.

GOVERNMENT OF LESOTHO (2005) ICT Policy for Lesotho Final. Maseru, Lesotho.

GOVERNMENT OF MALAWI (2003a) Malawi Information and Communications Technology (ICT) Policy. Lilongwe, Ministry of Information.

GOVERNMENT OF MALAWI (2003b) Malawi National HIVIAIDS Policy. Lilongwe, Government of Malawi.

HARBER, C. (2004) Schooling As Violence: How Schools Harm Pupils and Societies. New York, Routledge.

HARRIS, D. (1987) Openness and Closure in Distance Education. London, Falmer.

HELD, D. (2004) Global Covenant: The Social Democratic Alternative to the Washington Consensus. Cambridge, Polity.

HOOGVELT, A. (2001) Globalization and the Postcolonial World. Houndmills, Palgrave.

LENTELL, H. (2004) Framing policy for open and distance learning. Policy for Open and Distance Learning. London, RoutledgeFalmer.

LEWIN, K. and STUART, J. (2003) Researching Teacher Education: New Perspectives on Practice, Performance and Policy. Multi-site Teacher Education Research Study: Synthesis Report. London, Department for International Development.

LEWIS, R. (1990) Open learning and the misuse of language: a response to Greville Rumble. Open Learning: The Journal of Open and Distance Learning, 5, 3-8.

LITTLE, A. (2006) Education for All and Multigrade Teaching: Challenges and Opportunities, Dordrecht, Springer.

LITTLE, A. (2008) EFA Politics, Policies and Progress. Sussex, University of Sussex.

MINISTRY OF EDUCATION (Lesotho) (2001) Draft Policy Document on Non Formal Education. Ministry of Education Lesotho.

MINISTRY OF EDUCATION (Lesotho) (2005) Draft Final Statistical Bulletin. Ministry of Education Lesotho. Unpublished.

MINISTRY OF EDUCATION AND TRAINING (Lesotho) (2005) Education Sector Strategic Plan 2005-2015. Maseru, Ministry of Education and Training.

MINISTRY OF EDUCATION (Malawi) (n.d.) Combatting HIV and AIDS in the Education Sector in Malawi, Strategic Plan 2005-2008. Lilongwe, Government of Malawi.

MINISTRY OF EDUCATION AND VOCATIONAL TRAINING (Malawi) (2006) Malawi National Education Sector Plan. Lilongwe, Malawi, Ministry of Education and Vocational Training. 
NATIONAL AIDS COMMISSION (2005) National AIDS Commission Plan, Lesotho. National AIDS Commission, Government of Lesotho.

NATIONAL AIDS COMMISSION (2007) National AIDS Commission Plan, Lesotho. National AIDS Commission, Government of Lesotho.

NATIONAL STATISTICAL OFFICE and ORC MACRO (2005) Malawi Demographic and Health Survey 2004. Calverton, Maryland, National Statistical Office (Malawi) and ORC Macro. Available from: http://www.measuredhs.com/pubs/pdf/FR175/FR-175-MW04.pdf

NYABANYABA, T. (2008). The use of Open, Distance and Flexible Learning (ODFL) initiatives to open up access to education in the context of high HIV and AIDS prevalence rates: the case of Lesotho. SOFIE Opening Up Access Series no.4. London, Institute of Education. Available from: http://www.ioe.ac.uk/sofie/publications.html

PARSONS, T. (1983) The school class as a social system: some of its functions in American society. In COSIN, B. and HALES, M. (Eds.) Education, Policy and Society: Theoretical Perspectives. London, Routledge.

PERRATON, H. D. (2007) Open and Distance Learning in the Developing World. London, Routledge.

POGGE, T. W. M. (2002) World Poverty and Human Rights: Cosmopolitan Responsibilities and Reforms. Cambridge, Polity.

PRIDMORE, P. \& YATES, C. (2006) The Role of Open, Distance and Flexible Learning (ODFL) in HIVIAIDS Prevention and Mitigation for Affected Youth in South Africa and Mozambique. London, DFID.

RUMBLE, G. (1989) 'Open learning', 'Distance learning', and the misuse of language. Open Learning: The Journal of Open and Distance Learning, 4, 28-36.

SAYED, Y. and SOUDIEN, C. (2003) (Re) Framing Education Exclusion and Inclusion Discourses: Limits and Possibilities. IDS Bulletin, 34, 9-19.

STREULI, N. and MOLENI, C.M. (2008). Education and HIV and AIDS in Malawi: The role of open, distance and flexible learning. SOFIE Opening Up Access Series no.3. London, Institute of Education. Available from: http://www.ioe.ac.uk/sofie/publications.html

SWIFT, A. (2006) Political Philosophy: A Beginners' Guide for Students and Politicians. Cambridge, Polity Press.

UNAIDS (2006) 2006 Report on the global AIDS epidemic: A UNAIDS 10th anniversary special edition. Geneva, UNAIDS.

UNDP (2007) Human Development Report 2007/2008. Fighting climate change: Human solidarity in a divided world. New York, UNDP

UNESCO/UNICEF (2005) Children Out of School: Measuring Exclusion for Primary Education. Montreal, UNESCO Institute for Statistics.

UNESCO (2006) EFA Global Monitoring Report 2007: Strong Foundations: Early Childhood Care and Education. Paris, UNESCO Publishing.

UNESCO (2007) EFA Global Monitoring Report 2008: Education for All by 2015 Will we make it? Paris, UNESCO Publishing.

UNICEF (2006) The State of the World's Children 2007: Women and Children - The double dividend of gender equality. New York, UNICEF.

UNTERHALTER, E. (2007) Gender, Schooling and Global Social Justice. London, Routledge.

WARE, L. (2004) Ideology and the politics of (in) exclusion. New York, Peter Lang.

WHO (2006) The World Health Report 2006: Working together for health. Geneva, World Health Organization.

WILLIS, P. E. (1977) Learning to Labour: How Working Class Kids Get Working Class Jobs. Aldershot/Gower, Saxon House/Teakfield.

WORLD BANK (2005) World Development Report 2006: Equity and Development. Washington DC, The World Bank. 
YATES, C. (2000) Outcomes: What Have We Learned? In YATES, C. and BRADLEY, J. (Eds.) Basic Education at a Distance. London, RoutledgeFalmer.

YATES, C. \& PONTEFRACT, C. (2006) Southern African Development Community (SADC): Open and Distance Learning Capacity Building Project. Tunis, African Development Bank.

YOUNG, M. (1962) Is your child in the unlucky generation? Where, 10.

YOUNG, M. F. D. (1971) Knowledge and Control: New Directions for the Sociology of Education. Collier-Macmillan. 


\section{SOFIE}

Department of Education and International Development Institute of Education 20 Bedford Way London WC1H OAL

United Kingdom

Tel: + 44 (0) 2076126152

Email: m.harri@ioe.ac.uk

Website: www.ioe.ac.uk/sofie 